\title{
Integrative taxonomy reveals a rare and new cusk-eel species of Luciobrotula (Teleostei, Ophidiidae) from the Solomon Sea, West Pacific
}

\author{
Man-Kwan WONG ${ }^{1}$, Mao-Ying $\mathrm{LEE}^{2}$ \& Wei-Jen CHEN ${ }^{\circledR 3, *}$ \\ ${ }^{1,3}$ Institute of Oceanography, National Taiwan University, No.1, Sec. 4, Roosevelt Road, \\ Taipei 10617, Taiwan. \\ ${ }^{2}$ Marine Fisheries Division, Fisheries Research Institute, Council of Agriculture, No. 199, \\ Heyi Road, Keelung 202008, Taiwan. \\ *Corresponding author: wjchen.actinops@gmail.com \\ ${ }^{1}$ Email: Jun.mkwong@gmail.com \\ ${ }^{2}$ Email: coleopetera@gmail.com

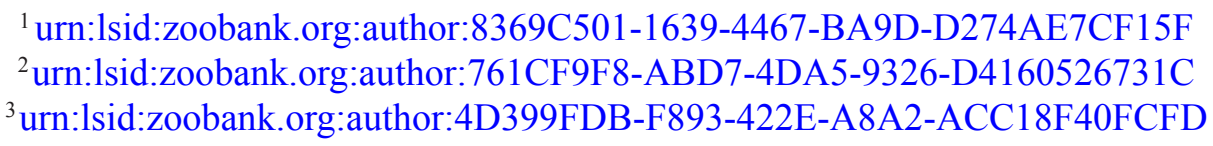

\begin{abstract}
With six valid species, Luciobrotula is a small genus of the family Ophidiidae, commonly known as cusk-eels. They are benthopelagic fishes occurring at depths ranging from 115-2300 $\mathrm{m}$ in the Atlantic, Indian, and Pacific Oceans. Among them, Luciobrotula bartschi is the only known species in the West Pacific. Three specimens of Luciobrotula were collected from the Philippine Sea, Bismarck Sea, and Solomon Sea in the West Pacific during the AURORA, PAPUA NIUGINI, and MADEEP expeditions under the Tropical Deep-Sea Benthos program, and all of them were initially identified as $L$. bartschi. Subsequent examination with integrative taxonomy indicates that they belong to two distinct species, with the specimen collected from the Solomon Sea representing a new species, which is described here. In terms of morphology, Luciobrotula polylepis sp. nov. differs from its congeners by having a relatively longer lateral line (end of the lateral line below the $33^{\text {rd }}$ dorsal-fin ray) and fewer vertebrae (abdominal vertebrae 13, total vertebrae 50). In the inferred COI gene tree, the two western Pacific species of Luciobrotula do not form a monophyletic group. The genetic K2P distance between the two species is $13.8 \%$ on average at the $C O I$ locus.
\end{abstract}

Key words. Biodiversity exploration, DNA barcoding, Ophidiiformes, species delimitation, tropical deep-sea benthos.

Wong M.-K., Lee M.-Y. \& Chen W.-J. 2021. Integrative taxonomy reveals a rare and new cusk-eel species of Luciobrotula (Teleostei, Ophidiidae) from the Solomon Sea, West Pacific. European Journal of Taxonomy 750: 52-69. https://doi.org/10.5852/ejt.2021.750.1361

\section{Introduction}

Luciobrotula Smith \& Radcliffe, 1913, a rare deep-sea fish genus, is currently classified in the subfamily Neobythitinae (Ophidiidae). Representatives of this genus differ from other ophidiids by having a much 
WONG M.-K. et al., A new and rare species of Luciobrotula from the West Pacific

depressed head, much less (3-4) developed long gill rakers on the first gill arch, and one median and a pair of basibranchial tooth patches (Nielsen 2009). Currently, six species of Luciobrotula are considered valid (Nielsen 2009; Fricke et al. 2020): L. bartschi Smith \& Radcliffe, 1913, L. brasiliensis Nielsen, 2009, L. coheni Nielsen, 2009, L. corethromycter Cohen, 1964, L. lineata (Gosline, 1954), and L. nolfi Cohen, 1981. All of them are benthic dwellers and can usually be found in the tropical deep waters of continental slopes worldwide (Cohen 1974; Nielsen 2009). They are probably carnivorous, though only a single study mentioned a partially digested caridean shrimp found in the gut of $L$. corethromycter (Cohen 1964). Fishes in this genus are rarely caught and usually from benthic trawling over sand or mud bottoms at depths between 110 and 2300 m (Radcliffe 1913; Cohen 1964; Nielsen et al. 1999; Nielsen \& Møller 2008; Robertson et al. 2017). Among them, L. bartschi has the widest distribution in the IndoWest Pacific, ranging from the Gulf of Aden and South Africa, east to the Hawaiian Islands, and north to Japan. It is the only species previously known from the West Pacific (Nielsen 2009).

Luciobrotula bartschi was the first described species of the genus on the basis of a single specimen collected during the Albatross Philippines expedition 1907-1910 from the Palawan Passage at a depth of $686 \mathrm{~m}$ (Radcliffe 1913). Since its discovery and description, several advanced taxonomic studies have been performed. Cohen (1964) conducted the first taxonomic review of Luciobrotula. He synonymized the monotypic ophidiid genus Volcanus Gosline, 1954 with Luciobrotula after examining the type species, Volcanus lineatus Gosline, 1954, concluding that there were no apparent differences between the two genera. In the same study, he also provided the first identification key for three nominal species including a newly described one, L. corethromycter, from the Atlantic Ocean. Later, Cohen (1981) described $L$. nolfi from the East Pacific, which was previously often misidentified as L. bartschi or $L$. corethromycter. Nielsen et al. (1999) conducted a thorough revision on the taxonomy of ophidiiform fishes. In that study, they also revised the identification key for four nominal species within the Luciobrotula. Nielsen (2009) carried out the latest review study of Luciobrotula by describing two additional species, L. brasiliensis from Brazil in the West Atlantic, and L. coheni from the Gulf of Panama in the East Pacific as well as providing an updated identification key for all known species of the genus.

Over the last 13 years, a total of 498 ophidiid fish samples were collected during 14 biodiversity expeditions (mainly in the tropical West Pacific) undertaken by the Tropical Deep-Sea Benthos (TDSB) program (Bouchet et al. 2008) and the cooperative project between Taiwan and France entitled "TaiwanFrance marine diversity exploration and evolution of deep-sea fauna" (TFDeepEvo, 2013-2016). Among them, only three specimens of Luciobrotula were collected from the Philippine Sea, Bismarck Sea, and Solomon Sea. These specimens were tentatively identified as $L$. bartschi as this was the only nominal species known from the West Pacific. However, after re-examining them based on a mitochondrial gene, we found that they are genetically distinct from each other. The purpose of this study is to validate the specimen collected from the Solomon Sea as representing a new species of Luciobrotula by using an integrated approach in taxonomy (Dayrat 2005; Hung et al. 2017; Lo et al. 2017; Lee S.-H. et al. 2019). The new species is herein described and an updated identification key for congenic species is provided.

\section{Material and methods}

\section{Sample collection}

The three examined samples of Luciobrotula (sample ID: ASIZP 0913925, PNG1082, and PNG2363) were collected from the Philippine Sea, Bismarck Sea, and Solomon Sea (Fig. 1) during three TDSB expeditions, AURORA, PAPUA NIUGINI, and MADEEP, carried out in 2007, 2012, and 2014, respectively. Detailed information about the expeditions can be referenced at https://expeditions.mnhn.fr/. A small piece of muscle was excised from each sample and preserved in $95 \%$ ethanol for molecular examination. The specimens were then photographed before fixing with 10\% 
formalin and later transferred to $70 \%$ ethanol for long-term preservation. The specimens were deposited in the ichthyological collections of the NTUM and ASIZP.

\section{Institutional abbreviations}

NTUM = National Taiwan University Museums, Taipei

ASIZP $=$ Academia Sinica, Taipei

\section{Morphological examination}

The three specimens collected in this study and four voucher specimens of Luciobrotula bartschi (ASIZP 0070170, ASIZP 0063749, ASIZP 0066071, and ASIZP 0075076) from the East China Sea and South China Sea (Fig. 1) were morphologically examined (see below and Appendix). Methods for measuring, counting, and general terminology followed Nielsen (2009). Specimens were measured with a dial caliper to the nearest $0.1 \mathrm{~mm}$. Internal osteological characters were examined through radiographs. Color pattern was based on freshly collected specimens and photos, with additional information provided after preservation.

\section{DNA data collection}

Total genomic DNA was extracted from each tissue using a commercial DNA extraction kit and a robot (LabTurbo 48 Compact System extractor, Taigene Biosciences Corp., Taipei, Taiwan) following the manufacturer's protocols. The cytochrome c oxidase subunit I (COI) gene was chosen as a marker for molecular examination of the specimens. A polymerase chain reaction (PCR) was used to amplify the

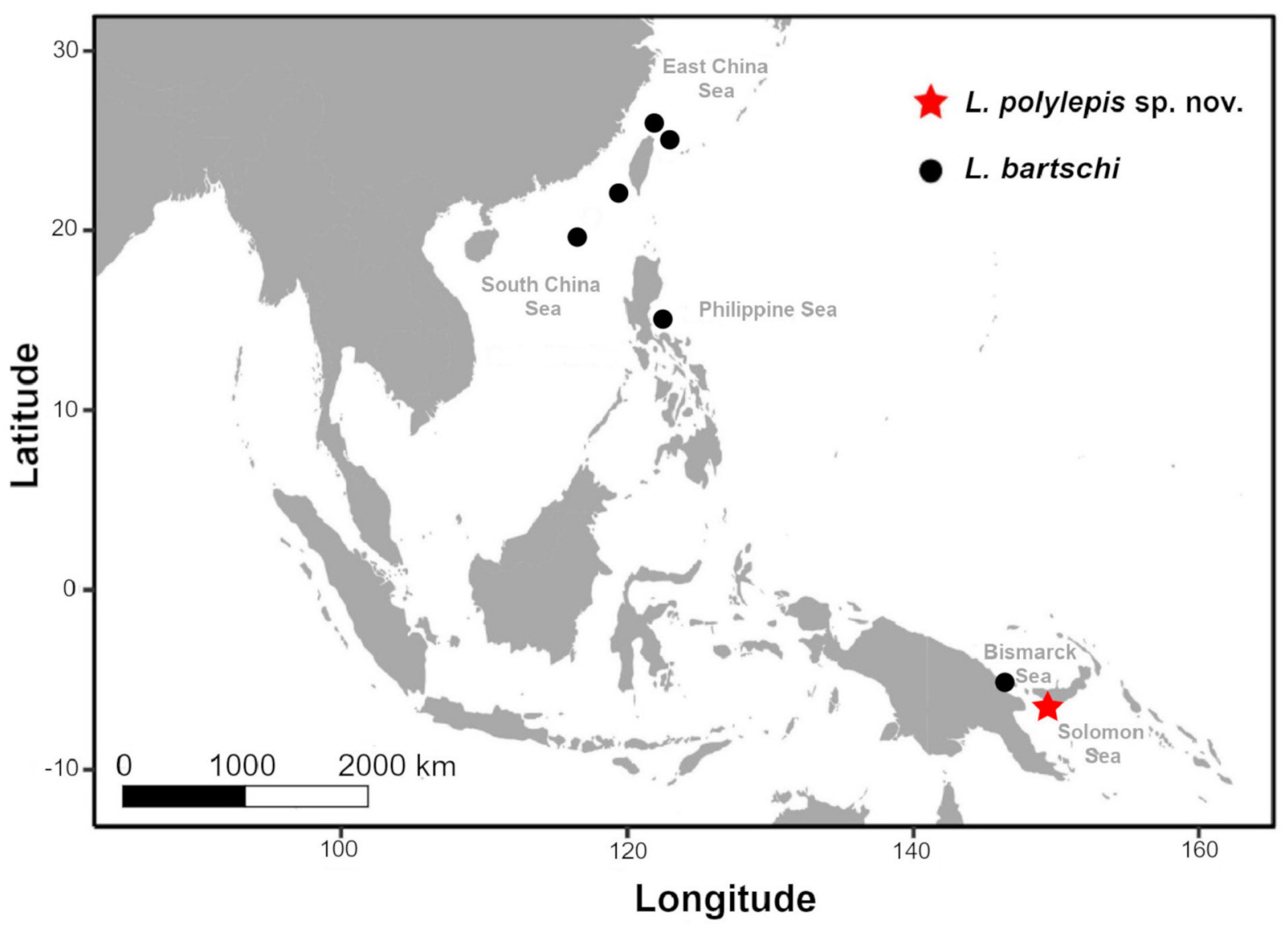

Fig. 1. Distribution of Luciobrotula polylepis sp. nov. (red star) and L. bartschi Smith \& Radcliffe 1913 (solid circles) based on specimens examined in this study. 
target gene fragment using the universal fish primers provided in Ward et al. (2005). PCR was carried out in a $25 \mu \mathrm{l}$ volume containing $9 \mu \mathrm{l}$ sterile distilled water, $0.5 \mu \mathrm{l}$ of each primer $(10 \mu \mathrm{M}), 12.5 \mu \mathrm{l}$ of EmeraldAmp MAX HS PCR Master Mix (TaKaRa), and $2.5 \mu$ of DNA template (around 10 20 ng). The thermal cycling profile for amplification consisted of an initial denaturation stage $\left(95^{\circ} \mathrm{C}, 60 \mathrm{sec}\right)$, followed by 35 cycles each with a denaturation step $\left(95^{\circ} \mathrm{C}, 30 \mathrm{sec}\right)$, an annealing step $\left(51^{\circ} \mathrm{C}, 30 \mathrm{sec}\right)$, and an elongation step $\left(72^{\circ} \mathrm{C}, 40 \mathrm{sec}\right)$, before a final extension stage $\left(72^{\circ} \mathrm{C}, 7 \mathrm{~min}\right)$. The successfully amplified products were then purified using the AMPure magnetic bead cleanup protocol (Agencourt Bioscience Corp.) and sequenced by Sanger sequencing at Genomics BioSci and Tech (Taipei). The same primers used for PCR were also used for sequencing; only the forward COI primer was used.

\section{Sequence alignment and phylogenetic analysis}

The obtained COI sequences were viewed and edited using CodonCode Aligner ver. 7.2.1 (CodonCode Corporation, Dedham, MA, USA) and were then aligned with eight other homologous sequences of Luciobrotula species retrieved from GenBank (NCBI, Nation Center for Biotechnology Information) $(n=7)$ and BOLD (The Barcode of Life Data Systems) $(n=1)$ (Table 1) using the automatic multiplealignment program MUSCLE (Edgar 2004). MEGA X (Kumar et al. 2018) software was further used to manage the compiled dataset and compute pairwise distances of compared sequences with the Kimura-2-Parameter model (K2P) (Kimura 1980). The phylogenetic analysis was conducted based on the compiled $C O I$ dataset using the maximum likelihood method (ML) with the nucleotide substitution model GTR $+\mathrm{G}$ as implemented in the software RAxML ver. 8.0.4 (Stamatakis 2014). Nodal support was assessed with bootstrapping (Felsenstein 1985) under the ML criterion, based on 1000 pseudoreplicates. Neobythites bimarginatus Fourmanoir \& Rivaton, 1979 and Neobythites stigmosus Machida, 1984 were used as outgroups to root the inferred COI tree.

\section{Species delimitation analysis}

The same COI gene dataset was used in three DNA-based species delimitation analyses, Automatic Barcode Gap Discovery (ABGD) (Puillandre et al. 2012), Bayesian based Poisson Tree Processes (bPTP) (Zhang et al. 2013), and Character-Based DNA Barcoding (CBB) (Desalle et al. 2005). ABGD is a tool for detecting significant differences between intra- and interspecific variation (barcode gap) by examining pairwise genetic distances. Operational taxonomic units (OTUs) or putative species were redefined through the analytical algorithm. The analysis was performed at the web interface (https://bioinfo.mnhn.fr/abi/public/abgd/abgdweb.html) with the default value (1.5) for relative gap width $(\mathrm{X})$, and the intraspecific divergence $(\mathrm{P})$ value ( 0.001 to 0.1$)$ with 20 steps under the K2P distance.

bPTP is a method for delimiting species based on a rooted phylogenetic tree, and mutations are modeled as speciation or branching events. Here, we used the inferred COI gene tree (see above) as the input tree. The bPTP settings are: number of MCMC generations $=100000$; thinning $=100$; burn-in $=0.1$; and seed $=123$. The analysis was performed at the web interface available from https://species.h-its.org/.

CBB is a method derived from the standard DNA barcoding approach (Hebert et al. 2004; Ward et al. 2005). Instead of simple cut-off distance thresholds for delimiting the species presented in the DNA dataset, the putative species are identified through the presence or absence of discrete and unique nucleotide substitutions within the DNA sequences of taxa (Desalle et al. 2005; Rach et al. 2008; Brower et al. 2010; Guimarães et al. 2020). Here, MEGA X software and inferred COI gene tree were used to determine apomorphic nucleotide sites in L. polylepis sp. nov. at the COI locus. Numbering of the determined nucleotide sites starts from the first nucleotide of the gene defined through sequence alignment with the complete $C O I$ sequence retrieved from the whole mitochondrial genome of Neobythites unimaculatus Smith \& Radcliffe 1913 (AP018428: 5544-7094).

The congruent results from bPTP and ABGD analyses were considered to be primary support of the OTUs (i.e., inferred potential species); other criteria (CBB result, morphological evidence, etc.) were also used for final validation of delimited species. 


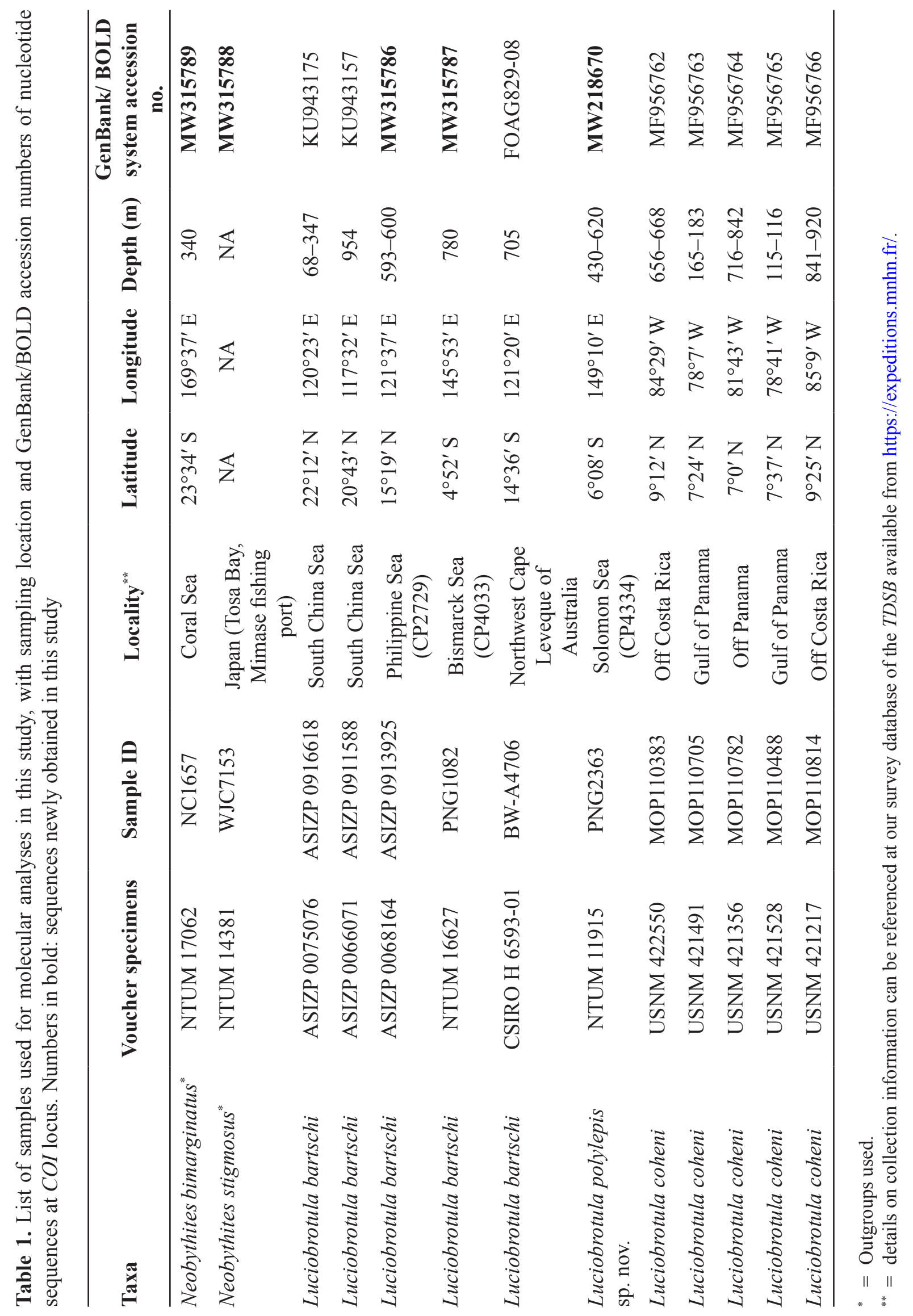




\section{Results}

Class Actinopterygii Klein, 1885

Order Ophidiiformes Berg, 1937

Family Ophidiidae Rafinesque, 1810

Genus Luciobrotula Smith \& Radcliffe, 1913

\section{Molecular phylogeny and species delimitation}

The COI dataset comprised 13 aligned sequences including three newly obtained sequences from the collected specimens, three additional sequences of L. bartschi from the South China Sea and Western Australia, five sequences of $L$. coheni from the Eastern Pacific, plus two outgroup sequences (Table 1). The length of the aligned sequences of the dataset is $618 \mathrm{bp}$. Figure 2 shows the phylogenetic tree inferred from the ML analysis based on the dataset. The monophyly of the genus Luciobrotula is strongly supported (bootstrap value $=98 \%$ ), and ingroup sequences form three clades or lineages among which two contain sequences from the two known species (Fig. 2). While two of our newly obtained sequences (ASIZP 0913925 and PNG1082) fall into the L. bartschi clade, the third one (PNG2363) appears to be a previously unknown lineage. Advanced species delimitation analyses with ABGD and bPTP based on the same $C O I$ dataset reveal a congruent result with a prediction of three OTUs, corroborating the phylogenetic finding (Fig. 2). The delimited OTUs (or inferred species) are genetically distinct from each other. The unknown lineage is distinct from others by 37 unique nucleotide sites based on CBB analysis. The average genetic distances measured using the K2P model among them are from 0.130 to 0.138 at the $C O I$ locus. Further morphological examination on the specimens indicates that the features of the sample collected from the Solomon Sea (PNG2363) are unique among all known Luciobrotula species (see below), and we validate it herein as a new species.

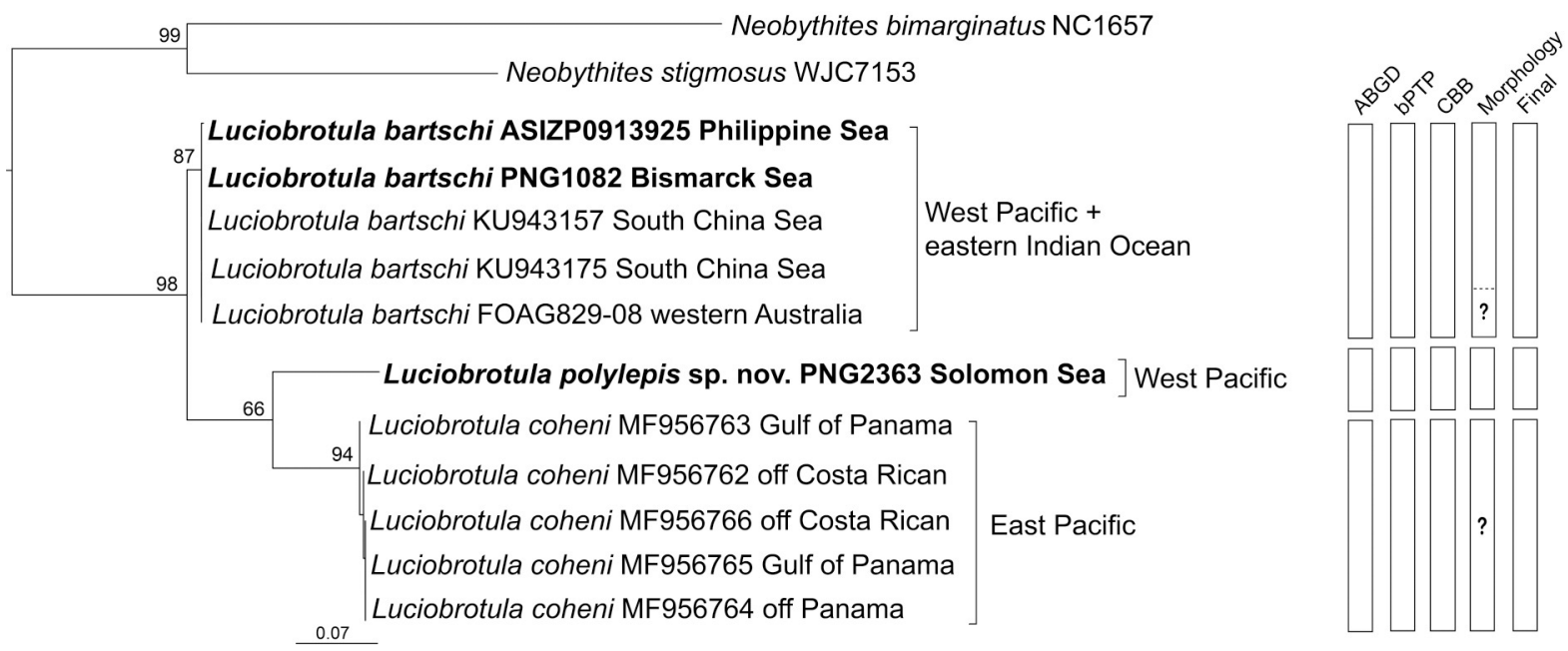

Fig. 2. Phylogenetic tree of species of Luciobrotula Smith \& Radcliffe 1913 inferred by the partitioned maximum-likelihood method with GTR $+\mathrm{G}$ nucleotide substitution model based on the COI gene dataset, and results from species delimitation based on COI gene analyses with ABGD, bPTP and CBB. Branch lengths are proportional to inferred nucleotide substitutions. Numbers at nodes represent bootstrap values in percentages. Values $<50 \%$ are not shown. Taxa names in bold indicate newly obtained sequences in this study. 


\title{
Description of new species
}

\author{
Luciobrotula polylepis sp. nov. \\ urn:lsid:zoobank.org:act:E7C043DA-005E-494F-9E00-21454E6E61BA
}

Figs 3-4; Table 2

\section{Diagnosis}

Luciobrotula polylepis sp. nov. is morphologically distinct from all congeners by the following combination of characters: lateral line ending below $33^{\text {rd }}$ dorsal-fin ray; dorsal-fin rays 86 , anal-fin rays 70 , precaudal vertebrae 13, total vertebrae 50; gill rakers 17 (3 long rakers and 14 dentigerous plates); longest gill raker $2.1 \% \mathrm{SL}$; height of posterior margin of maxilla $3.2 \% \mathrm{SL}$; distance from the snout to end of lateral line $60 \% \mathrm{SL}$; one interorbital pore and four occipital pores.

\section{Differential diagnosis}

The new species is most similar to L. brasiliensis because both share the low number of vertebrae. It differs from $L$. brasiliensis by having a much longer lateral line (ending at the $33^{\text {rd }}$ dorsal-fin ray vs ending at the $2^{\text {nd }}$ dorsal-fin ray), a slightly more posterior position of the anal-fin origin (first anal ray below dorsal ray no. $22 \mathrm{vs}$ first anal ray below dorsal ray no. 17), more pectoral-fin rays (32 vs 26), more gill rakers (17 vs 13-14), longer gill raker on first arch (2.1\% SL vs $1.2 \% \mathrm{SL})$.

Luciobrotula polylepis sp. nov. differs from L. bartschi (Figs 5-7) in having a slightly longer lateral line (ending at the $33^{\text {rd }}$ dorsal-fin ray vs the $18^{\text {th }}-26^{\text {th }}$ dorsal-fin ray) and narrower posterior margin of maxilla (3.2\% SL vs $3.6-4.7 \% \mathrm{SL})$.

It differs from $L$. coheni by having more anal-fin rays (70 vs 59-65), fewer total gill rakers (17 vs 21-26), a more anterior anal-fin origin (anterior anal-fin ray below $17^{\text {th }}$ vertebra vs anterior anal-fin ray below $21^{\text {st }}-22^{\text {nd }}$ vertebrae), a narrower interorbital space (3.5\% SL vs 3.9-5.6\% SL), and a narrower posterior margin of the maxilla (3.2\% SL vs $3.9-4.9 \% \mathrm{SL})$.

It differs from $L$. corethromycter by having fewer dorsal-fin rays (86 vs 91-96), fewer gill rakers (17 vs $18-21$ ), and anterior position of the anal-fin origin (first anal-fin ray below the $17^{\text {th }}$ vertebra vs first analfin ray below the $20^{\text {th }}-22^{\text {nd }}$ vertebrae).

It differs from $L$. nolf $i$ by having a slightly longer lateral line (ending at the $33^{\text {rd }}$ dorsal-fin ray vs ending at the $27^{\text {th }}-31^{\text {st }}$ dorsal-fin ray), slightly more anterior position of the anal-fin origin (first anal-fin ray below the $17^{\text {th }}$ vertebra vs first anal-fin ray below the $19^{\text {th }}-20^{\text {th }}$ vertebrae), smaller head $(23.9 \%$ SL vs $24.5-28.0 \% \mathrm{SL})$, and relatively deeper body (16.3\% SL vs $12.5-15.0 \% \mathrm{SL})$.

It differs from $L$. lineata by having a much longer lateral line (ending at the $33^{\text {rd }}$ dorsal-fin ray vs ending at the $2^{\text {nd }}$ dorsal-fin ray), fewer dorsal-fin rays (86 vs 92), more pectoral-fin rays (32 vs 26), shorter pelvic-fin rays (10.9\% SL vs $15.0 \% \mathrm{SL})$ and longer gill raker on the first arch $(2.1 \% \mathrm{SL}$ vs $0.7 \% \mathrm{SL})$. A detailed comparison between the new species and other congeners is provided in Table 2.

Along the COI gene, the following apomorphic sites are unique nucleotides from the only specimen of L. polylepis sp. nov. examined here; these nucleotide sites can be used for the molecular diagnosis of the species to differentiate it from L. coheni and L. bartschi examined in this study. Nos. 97 (C vs T), 120 (A vs $\mathrm{G}$ ), 147 ( $\mathrm{G}$ vs A), 177 ( $\mathrm{G}$ vs A), 180 (C vs T), 198 (C vs T), 219 ( $\mathrm{T}$ vs C), 225 (C vs T), 294 (C vs T), 321 (A vs C), 324 ( $\mathrm{G}$ vs A), 330 (A vs $\mathrm{G}$ ), 336 (A vs C), 348 ( $\mathrm{G}$ vs A or C), 363 ( $\mathrm{G}$ vs $\mathrm{T}$ or C), 369 ( $\mathrm{T}$ vs $\mathrm{C}$ ), 372 ( $\mathrm{A}$ vs $\mathrm{C}$ or $\mathrm{T}$ ), 375 (C vs T), 381 ( $\mathrm{G}$ vs $\mathrm{A}$ ), 387 (C vs T), 390 ( $\mathrm{T}$ vs $\mathrm{C}$ ), 405 (C vs T), 420 (A vs $\mathrm{G}$ or $\mathrm{C}$ ), 426 ( $\mathrm{T}$ vs $\mathrm{C}$ ), 465 ( $\mathrm{A}$ vs $\mathrm{C}$ or $\mathrm{G}$ ), 477 (A vs $\mathrm{G}$ ), 540 (A vs $\mathrm{G}$ ), 555 ( $\mathrm{G}$ vs $\mathrm{A}$ ), 565 ( $\mathrm{T}$ vs $\mathrm{C}$ ), 597 ( $\mathrm{T}$ vs $\mathrm{C}$ ), 603 ( $\mathrm{T}$ vs $\mathrm{A}$ ), 615 (C vs $\mathrm{A}), 648$ ( $\mathrm{T}$ vs $\mathrm{C}$ ), 682 (C vs $\mathrm{A}$ or $\mathrm{G}), 675$ (C vs $\mathrm{T}$ ), 684 (G vs $\mathrm{A})$, 687 ( T vs C). 
WONG M.-K. et al., A new and rare species of Luciobrotula from the West Pacific

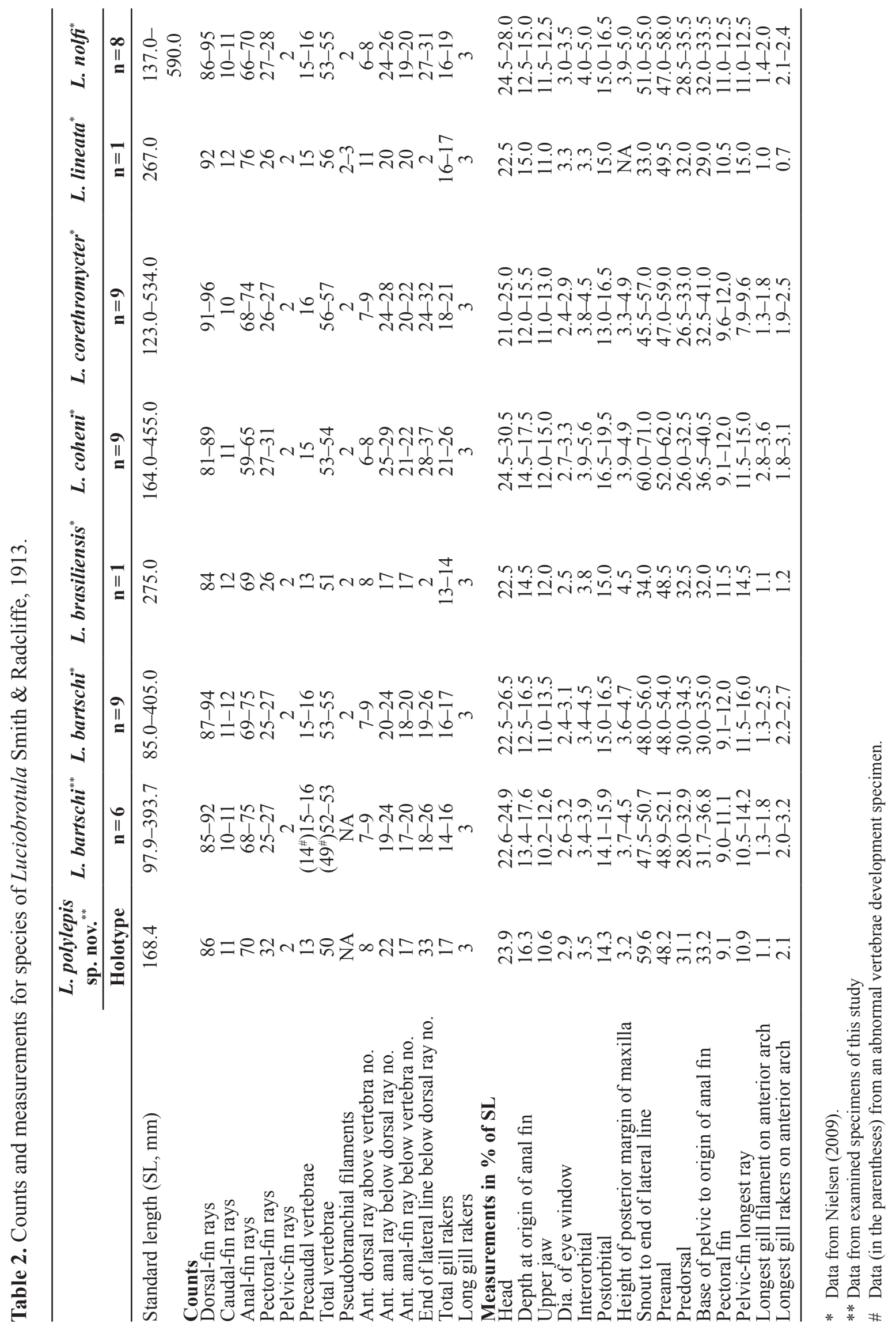




\section{Etymology}

The name polylepis is derived from the Greek 'poly', meaning 'many' or 'numerous', and 'lepis', meaning 'scales', in reference to the much longer lateral line and therefore more lateral line scales compared with $L$. bartschi, the only congener distributed in the West Pacific.

\section{Type material}

\section{Holotype}

SOLOMON SEA • 168.4 mm SL, sample ID: PNG2363; Ainto Bay, SE of New Britain Island, Papua New Guinea, Solomon Sea, West Pacific, stn CP4334; $6^{\circ} 08^{\prime}$ S, $149^{\circ} 10^{\prime}$ E; 430-620 m depth; 6 May 2014; R/V ALIS; French beam trawl; MADEEP expedition; GenBank registration: MW218670; NTUM 11915.

\section{Description}

Measurements and counts of the holotype given in Table 2. Body elongate with tapering caudal portion, snout and head slightly depressed; eye small and round, horizontal eye diameter about half of snout length. Mouth large, oblique; upper jaw reaching a vertical through the posterior margin of orbit,

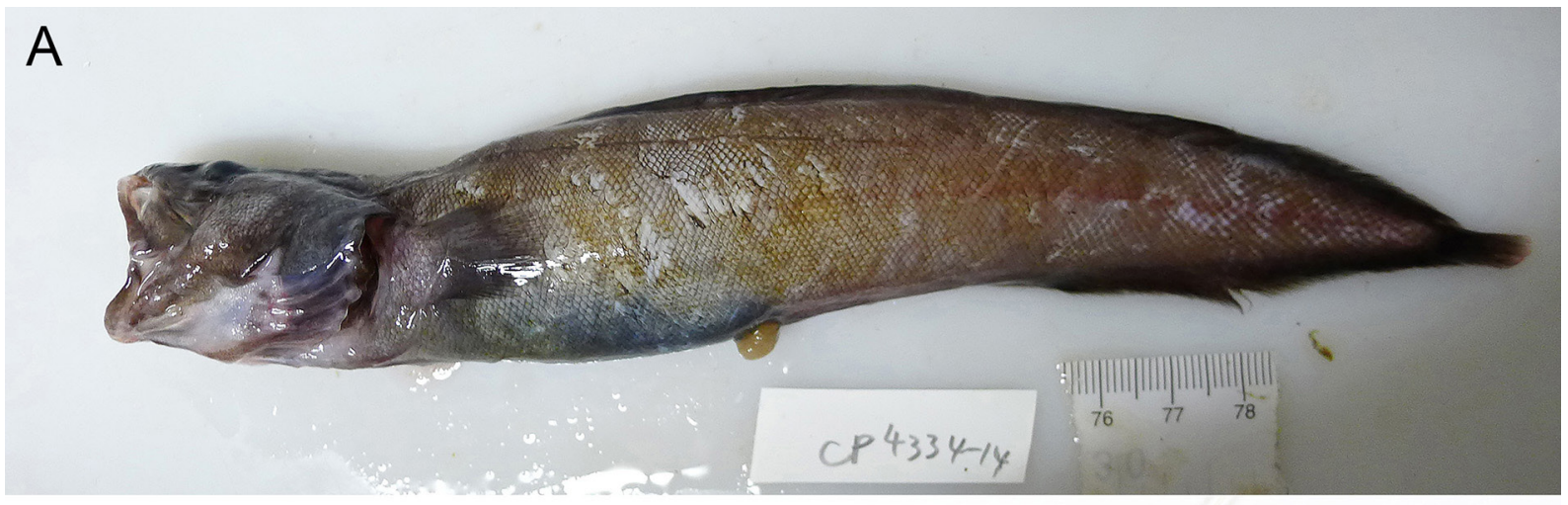

B

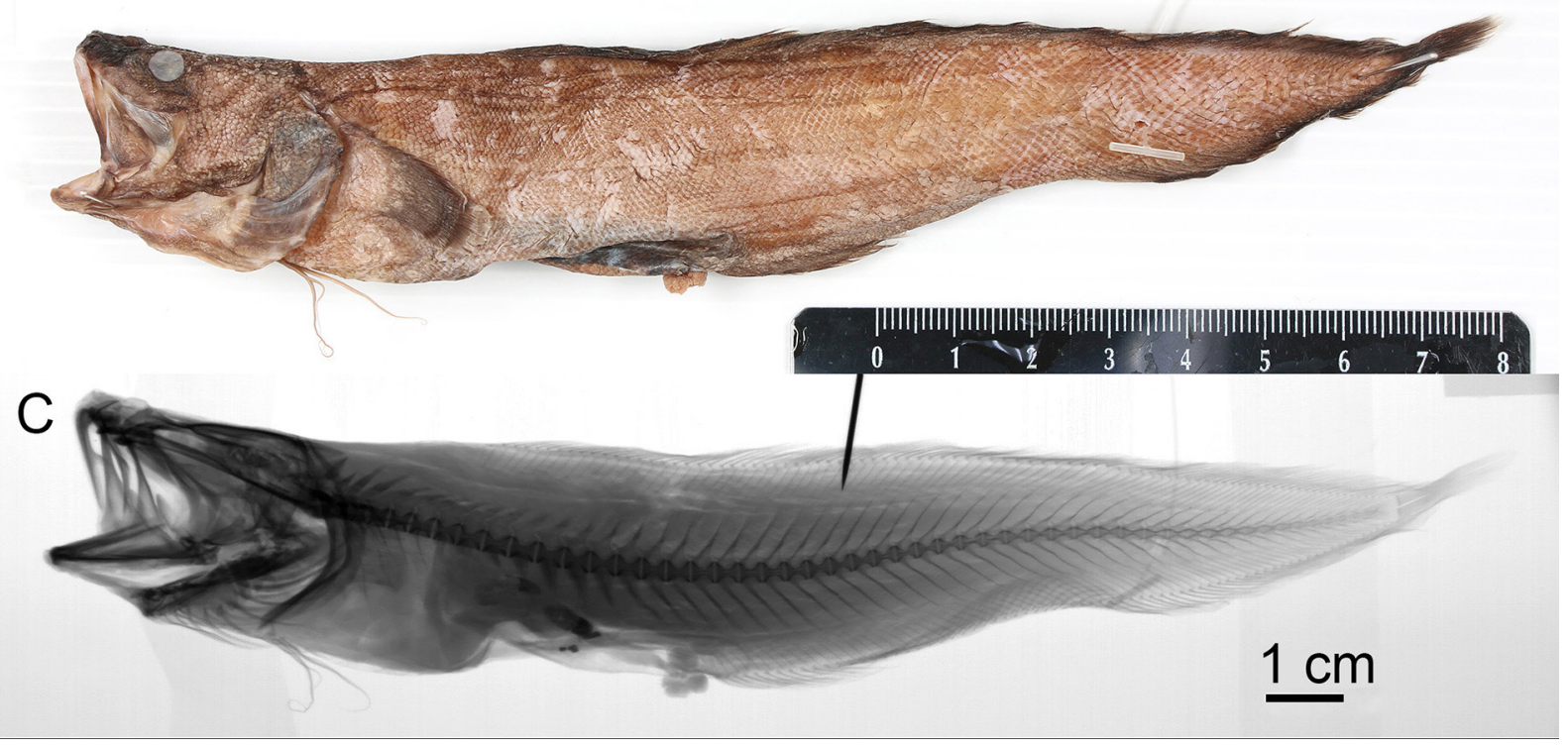

Fig. 3. Holotype of Luciobrotula polylepis sp. nov., $168.4 \mathrm{~mm}$ SL (NTUM 11915). A. Fresh specimen. B. Preserved specimen. C. Radiograph. Needle points to the lateral line end. 
posterior part vertically much extended, slightly protruding beyond lower jaw when mouth closed. Boomerang-formed vomer; palatine, and upper and lower jaw with many small, close-set, rather blunt teeth in several irregular rows; fang-like teeth absent in both jaws. One median and a pair of two large basibranchial tooth patches. Anterior nostril with low rim and placed midway between upper lip and posterior nostril, with small rounded flap rising from anterior rim. Posterior margins of preopercle, interopercle, and subopercle rounded, without spine. First gill arch with four finely dentigerous plates on upper branch, one long raker on the angle, and lower branch with two long rakers interspaced with 10 dentigerous plates (Fig. 4D); gill filaments ca 100, the longest about half as long as longest gill raker; pseudobranchial filament damaged, unavailable count.

Sensory pores are found all over head (Fig. 4A-B). Supraorbital with group of eight pores behind eye, five pores immediately above eye, and five small pores in a row on tip of snout, larger pore between flaps on tip of snout, and above each nostril, one interorbital pore, four occipital pores, six suborbital pores

A

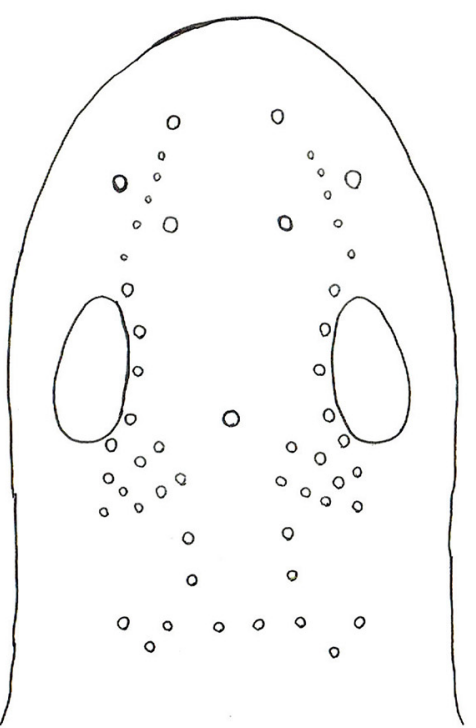

\section{$1 \mathrm{~mm}$}

C

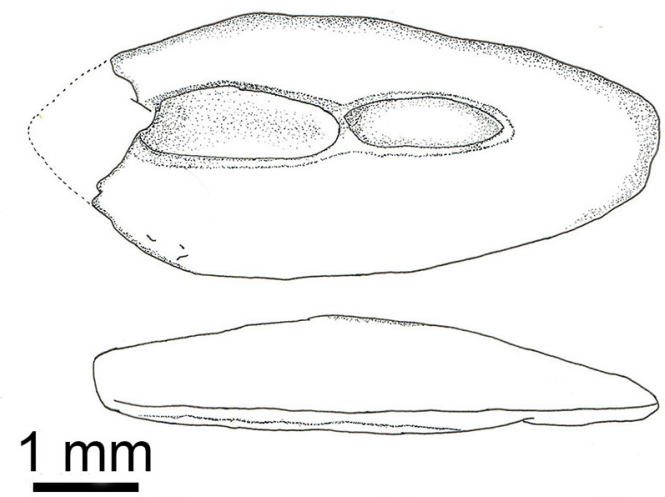

B

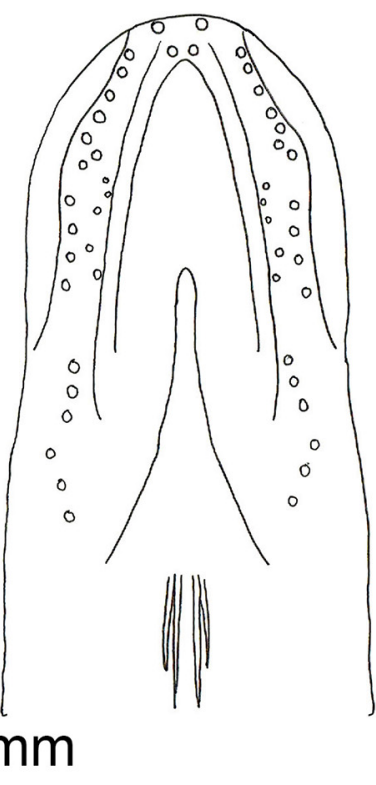

D

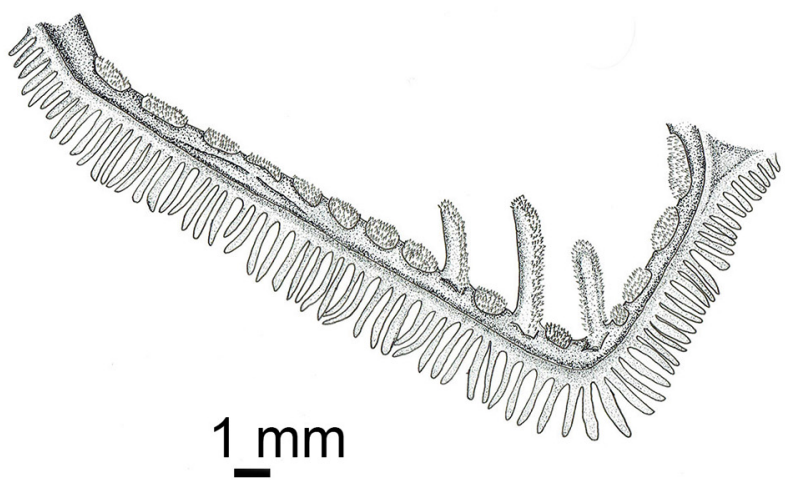

Fig. 4. Luciobrotula polylepis sp. nov., holotype (NTUM 11915). A. Dorsal view of sensory pores on head. B. Ventral view of sensory pores on head. C. Median and ventral view of right sagitta. D. First gill raker (left side). 
and four mandibular pores, 10 small pores close to lower jaw, between this row and mandibular having four small pores, and finally a row of six pores above posterior mandibular, two pores behind posterior end of maxilla, and preopercle with six pores.

Sagittal otolith is elongate and thin, about 2.5 times as long as high. Sulcus divided into ostium and cauda. Cauda is about $2 / 3$ of ostium (Fig. 4C). Due to the damaged anterior rim, the presence of an ostial channel could not be ascertained.

Body, top of head, and opercle covered with small cycloid scales, with ca 72 scales in oblique line from origin of anal fin forwards and ca 111 scales from upper part of gill slit to base of caudal fin; single lateral line originating at upper angle of opercle and extending posteriorly in straight line placed about midway between midline and profile of body, ending below $33^{\text {rd }}$ dorsal-fin ray. Dorsal-fin origin above end of pectoral fin; anal-fin origin at about mid-body of fish, pectoral fin placed medially and pelvic fin reaching one third from base to anal fin.

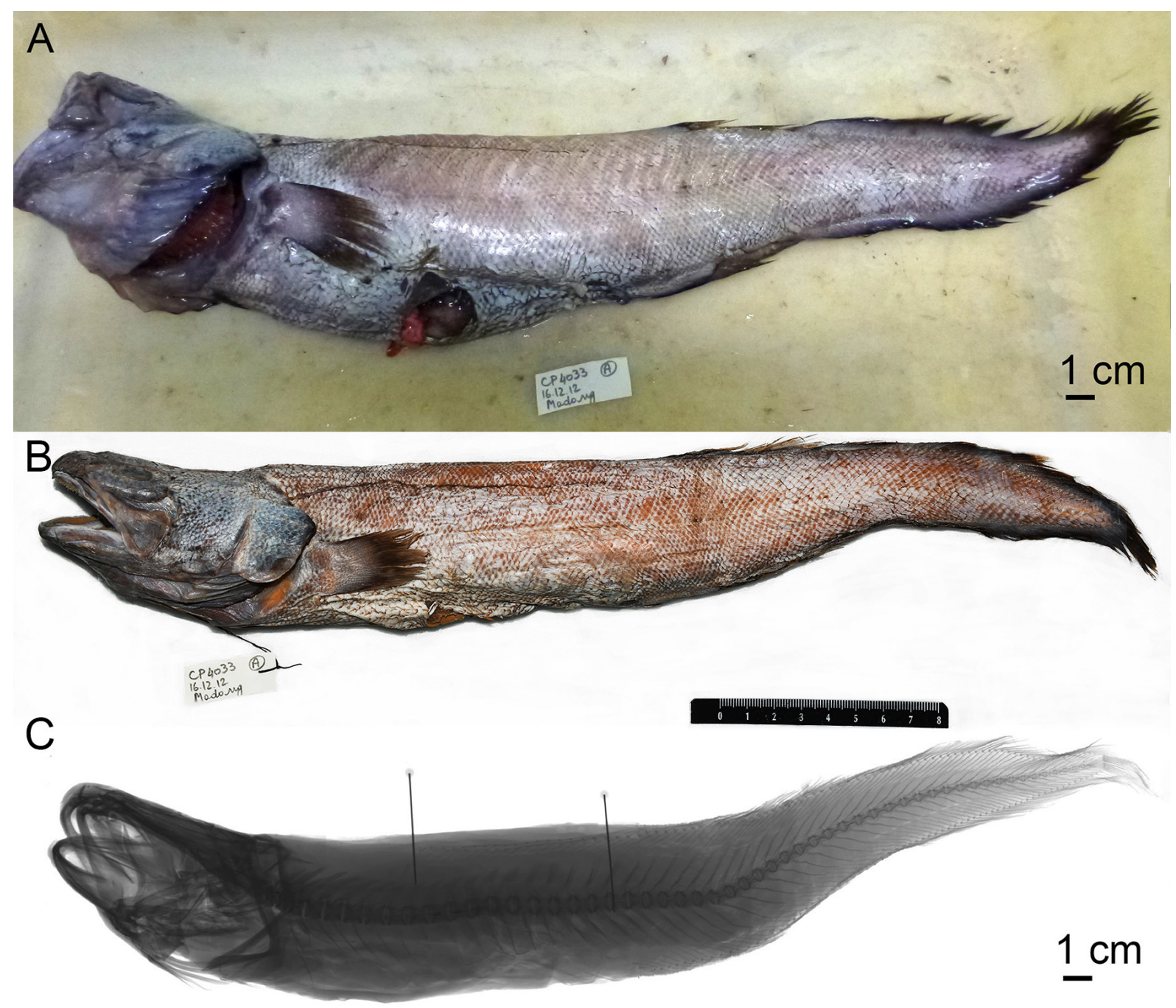

Fig. 5. Luciobrotula bartschi Smith \& Radcliffe 1913. Voucher specimen, $393.7 \mathrm{~mm}$ SL (NTUM 16627). A. Fresh specimen. B. Preserved specimen. C. Radiograph. Second needle points to the end of the lateral line. 
Third neural spine pointed, length of first spine half as long as second spine (Fig. 3C), neural spines of posterior 10 pre-caudal vertebrae with blunt tips and broad bases, $4^{\text {th }}-11^{\text {th }}$ precaudal vertebrae with broad bases and depressed neural spines, $7^{\text {th }}-13^{\text {th }}$ precaudal vertebrae with parapophyses, and pleural ribs on $3^{\text {rd }}-6^{\text {th }}$ precaudal vertebrae. Epipleural ribs hard to observe.

Head brown; body brownish-yellow with bluish-brown abdomen (Fig. 3A). Dorsal, pectoral, anal, and caudal fins black. Color of preserved specimen similar to that of fresh specimens, the head and body uniformly brown with dark bluish-brown abdomen (Fig. 3B).

\section{Distribution}

Possibly endemic to waters off Papua New Guinea; the only known specimen was collected on the SE continental slope of New Britain Island, Papua New Guinea, at depths of 430-620 m (Fig. 1).

\section{Accompanying fauna}

Monomitopus sp. and Glyptophidium lucidum Smith \& Radcliffe, 1913 were the only two other ophidiids collected along with $L$. polylepis sp. nov., in addition to Epigonus atherinoides (Gilbert, 1905) (Epigonidae Poey, 1861) (Okamoto et al. 2018). The mud bottom living invertebrates collected from the same site included sea cradles, sea snails, sea stars, deep-sea barnacles, decapods (https://expeditions.mnhn.fr/campaign/madeep/event/cp4334\#les_photos), and a recently described deep-sea spider crab, Tunepugettia corbariae Lee, Richer de Forges \& Ng 2019 (Epialtidae MacLeay, 1838) (Lee B.-Y. et al. 2019).

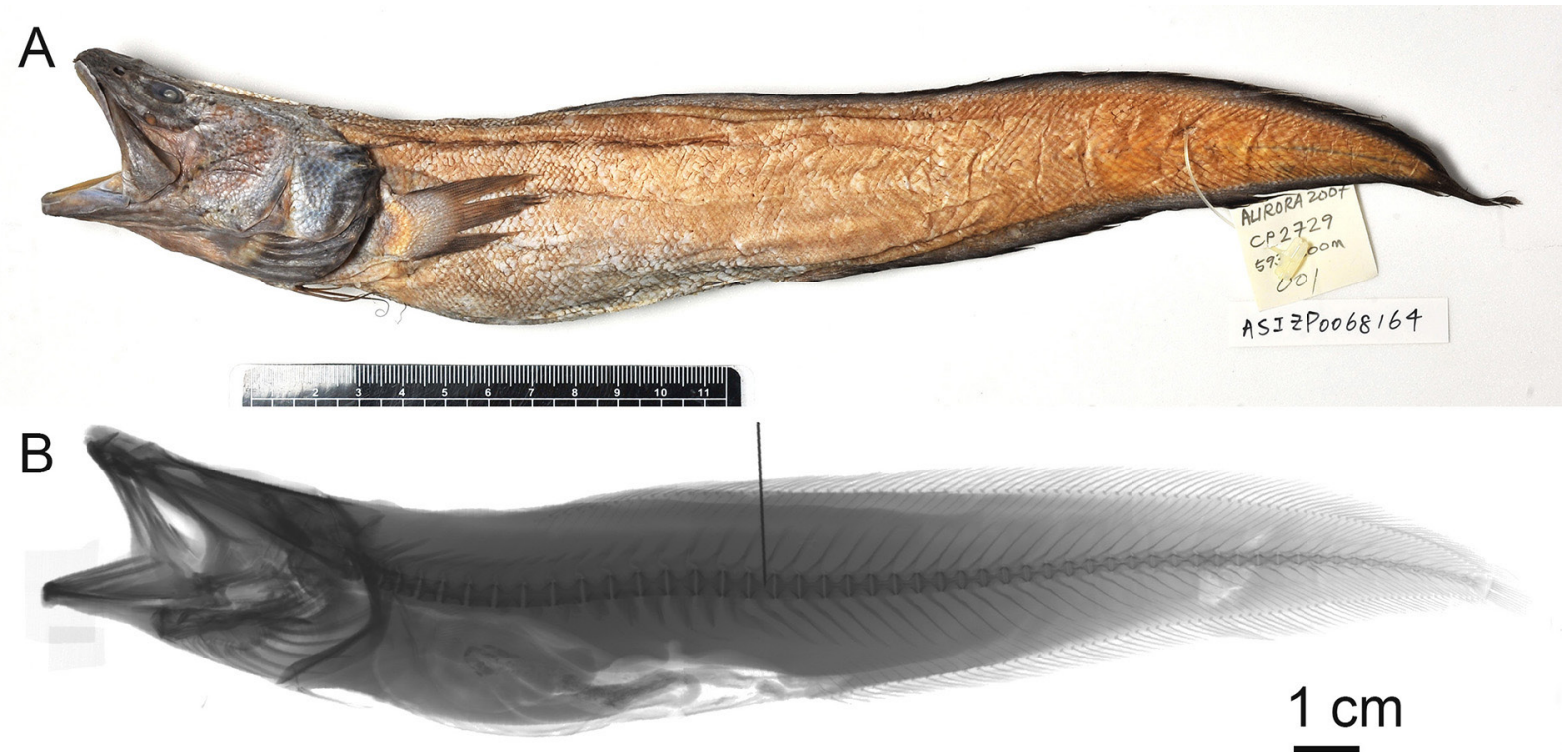

Fig. 6. Luciobrotula bartschi Smith \& Radcliffe 1913. Voucher specimen, $301.7 \mathrm{~mm}$ SL (ASIZP 0068164). A. Preserved specimen. B. Radiograph. Needle points to the end of the lateral line. 


\title{
Key to all known species of Luciobrotula Smith \& Radcliffe, 1913
}

\author{
(modified from Nielsen 2009)
}

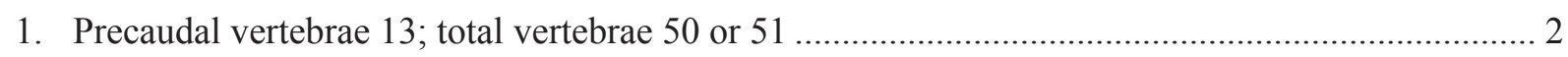

- Precaudal vertebrae 15 or 16 ; total vertebrae $52-57$....................................................................... 3

2. Lateral line ending at $2^{\text {nd }}$ dorsal-fin ray; total gill rakers $13-14$

- Lateral line ending at $33^{\text {rd }}$ dorsal-fin ray; total gill rakers 17

L. brasiliensis Nielsen, 2009 (off Brazil)

L. polylepis sp. nov. (off Papua New Guinea)

3. Lateral line short and distinct, ending at $2^{\text {nd }}$ dorsal-fin ray ....L. lineata (Gosline, 1954) (off Hawaii)

- Lateral line long, usually indistinct, ending at $19^{\text {th }}-37^{\text {th }}$ dorsal-fin ray......

4. Dorsal-fin rays 81-89; anal-fin rays 59-65; first gill arch with 3 developed rakers and 18-23 dentigerous plates; longest filaments on first gill arch 2.8-3.6\% SL ......... L. coheni Nielsen, 2009 (East Pacific)

- Dorsal-fin rays 86-96; anal-fin rays 66-75; first gill arch with 3-4 developed rakers and 12-18 dentigerous plates; longest filaments on fist gill arch 1.3-2.7\% SL ............................................. 5

5. Four occipital pores, one interorbital pore; first anal-fin ray below $18^{\text {th }}-24^{\text {th }}$ dorsal-fin rays; dorsal rim of otolith without concavity (large specimens)

.L. bartschi Smith \& Radcliffe, 1913 (Indo-West Pacific)

- Pores absent on occipital and interorbital region; first anal-fin ray below $24^{\text {th }}-28^{\text {th }}$ dorsal-fin rays; dorsal rim of otolith with or without concavity......

6. Head brown; otolith with a distinct concavity in dorsal rim in specimens larger than $300 \mathrm{~mm}$ SL; total vertebrae $56-57$; longest pelvic-fin ray $7.9-9.6 \% \mathrm{SL}$

L. corethromycter Cohen, 1964 (Gulf of Mexico, Caribbean Sea)

- Head pale; otolith without a distinct concavity in dorsal rim in specimens larger than $300 \mathrm{~mm}$ SL; total vertebrae 53-55; longest pelvic-fin ray $11.0-12.5 \%$ SL

L. nolfi Cohen, 1981 (tropical East Atlantic)

\section{Discussion}

The number of vertebrae is an important diagnostic character in distinguishing species of Luciobrotula. Based on that, the species of this genus can be split into two groups, either possessing 13 precaudal vertebrae or possessing 15 or 16 precaudal vertebrae. Our newly described species, L. polylepis sp. nov., is grouped together with $L$. brasiliensis in having a lower precaudal vertebrae count. Another group with a higher precaudal vertebrae count consists of $L$. bartschi, L. coheni, L. corethromycter, L. lineata, and L. nolfi. In this study, six specimens of $L$. bartschi were examined (Table 2). We noticed that one of them (ASIZP 0063749) failed to reach the measurement range of the species. In fact, ASIZP 0063749 has fewer precaudal vertebrae (14 instead of 15-16) and fewer total vertebrae (49 instead of 52-55). When we further examined this specimen through radiographs, we observed that the $24^{\text {th }}$ and $25^{\text {th }}$, and the $28^{\text {th }}$ and $29^{\text {th }}$ vertebrae of ASIZP 0063749 were fused together (Fig. 7) and that it should be regarded as a specimen with abnormal vertebrae. In addition to the number of vertebrae, the lateral line length is another important character for identifying species of Luciobrotula. Luciobrotula brasiliensis and L. lineata possess lateral lines reaching below the second dorsal-fin ray; others, including L. polylepis sp. nov., possess lateral lines reaching beyond the $19^{\text {th }}$ dorsal-fin ray.

Among the species of Luciobrotula, L. bartschi is the only known widespread species. In the West Pacific, its distribution ranges from the Philippines north to Japan and west to Hawaii; it was also 
recorded from Papua New Guinean waters, first by Nielsen \& Møller (2008) (n=1), and later by Fricke et al. (2014) $(\mathrm{n}=1)$. However, the specimen of 'L. bartschi' (NTUM 10054) examined by Fricke et al. (2014) represented a misidentification. Upon our reexamination, we found that it possesses a combination of characters (a copulatory organ and the caudal fin fused with the dorsal and anal fins) that matches fishes from another ophidiiform family, the Bythitidae Gill, 1861 (Møller et al. 2016). Nevertheless, the six samples of $L$. bartschi examined in this study were all collected from sites within the reported range of the species (Fig. 1). The new species is possibly endemic to Papua New Guinea, as it is so far known from its type locality only. These two western Pacific species appear to share a similar bathymetric range (430-620 m vs 400-2283 m depth) and habitat (mud bottom), and both are found in Papua New Guinean waters. Certainly, their distribution and ecology require more investigations.

Specimens of Luciobrotula seem to be rare. Despite intensive sampling efforts from either local organizations in Taiwan or international expeditions through the TDSB for over a decade, only a few specimens were made available for scientific investigations. The difficulty in sampling has limited our understanding of biodiversity, phylogeny, biogeography, and ecology of deep-sea fishes such as those from the rare genus Luciobrotula or others (e.g., Chelidoperca Boulenger, 1895) (Lee S.-H. et al. 2019). In spite of that, in this study we successfully uncover the hidden diversity of the Luciobrotula in the West Pacific using an integrated approach in taxonomy and conduct the first phylogenetic study of Luciobrotula. From the inferred phylogenetic tree, the two western Pacific species of Luciobrotula are shown to be distantly related to each other despite their geographic proximity. Our preliminary phylogenetic result also indicates that the species (L. bartschi and L. coheni) sharing a similar morphology may not be closely related.

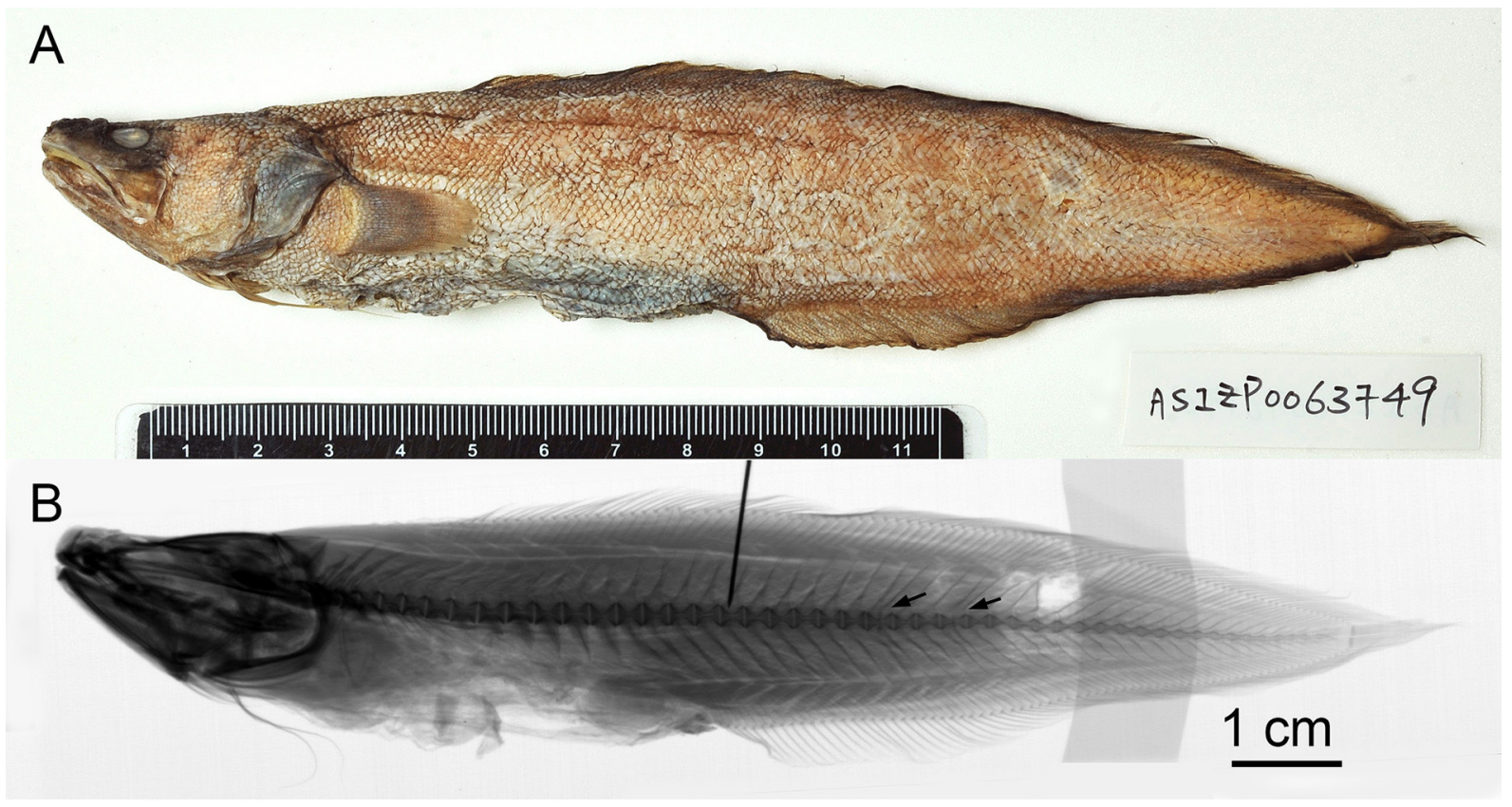

Fig. 7. Luciobrotula bartschi Smith \& Radcliffe 1913. Voucher specimen, $181.6 \mathrm{~mm}$ SL (ASIZP 0063749). A. Preserved specimen. B. Radiograph. Needle points to the end of the lateral line. Arrows point to fused vertebrae. 


\section{Acknowledgments}

We would like to thank the participants of AURORA, PAPUA NIUGINI, and MADEEP oceanography expeditions, and the crew of R/V DA-BFAR and ALIS in organizing the survey and collecting the samples under the TDSB Program. The Papua New Guinea expeditions were also supported from Papua New Guinea's National Fisheries Authority and conducted under a Memorandum of Understanding with the University of Papua New Guinea (UPNG), and with a permit from the Papua New Guinea Department of Environment and Conservation (DEC). We also thank S.-P. Huang (ASIZP) and H.-C. Lin (NTUM) for specimen management and assistance, and the anonymous reviewers and the editor (F.P. Ottoni) whose comments improved the manuscript. This study was supported by research funding from the Ministry of Science and Technology, Taiwan (MOST 102-2923-B-002-001-MY3, MOST 107-2611M-002-007- and MOST 108-2611-M-002-012-MY2 to W.-J. Chen) and the French National Research Agency (ANR 12-ISV7-0005-01 to S. Samadi).

\section{References}

Bouchet P., Héros V., Lozouet P. \& Maestrati P. 2008. A quarter-century of deep-sea malacological exploration in the South and West Pacific: Where do we stand? How far to go. Tropical Deep-Sea Benthos 25: 9-40.

Brower A.V. 2010. Alleviating the taxonomic impediment of DNA barcoding and setting a bad precedent: names for ten species of 'Astraptes fulgerator' (Lepidoptera: Hesperiidae: Eudaminae) with DNA-based diagnoses. Systematics and Biodiversity 8 (4): 485-491.

https://doi.org/10.1080/14772000.2010.534512

Cohen D.M. 1964. A review of the ophidioid fish genus Luciobrotula with the description of a new species from the western North Atlantic. Bulletin of Marine Science 14 (3): 387-398.

Cohen D.M. 1974. The ophidioid fish genus Luciobrotula in the Hawaiian Islands. Pacific Science 28 (2): 109-110.

Cohen D.M. 1981. New and rare ophidiiform fishes from the eastern Atlantic: Canary Islands to the Cape of Good Hope. Proceedings of the Biological Society of Washington 94 (4): 1085-1103.

Dayrat B. 2005. Towards integrative taxonomy. Biological Journal of the Linnean Society 85 (3): $407-$ 417. https://doi.org/10.1111/j.1095-8312.2005.00503.x

Desalle R., Egan M.G. \& Siddall M. 2005. The unholy trinity: taxonomy, species delimitation and DNA barcoding. Philosophical Transactions of the Royal Society B 360: 1905-1916.

https://doi.org/10.1098/rstb.2005.1722

Edgar R.C. 2004. MUSCLE: multiple sequence alignment with high accuracy and high throughput. Nucleic Acids Research 32 (5): 1792-1797. https://doi.org/10.1093/nar/gkh340

Felsenstein J. 1985. Confidence limits on phylogenies: an approach using the bootstrap. Evolution 39 (4): 783-791. https://doi.org/10.1111/j.1558-5646.1985.tb00420.x

Fricke R., Allen G.R., Andréfouët S., Chen W.-J., Hamel M.A., Laboute P., Mana R., Hui T.H. \& Uyeno D. 2014. Checklist of the marine and estuarine fishes of Madang District, Papua New Guinea, western Pacific Ocean, with 820 new records. Zootaxa 3832 (1): 1-247.

https://doi.org/10.11646/zootaxa.3832.1.1

Fricke R., Eschmeyer W.N. \& Van der Laan R. 2020. Catalog of Fishes: Genera, Species, References. Available from http://researcharchive.calacademy.org/research/ichthyology/catalog/fishcatmain.asp [accessed Oct. 2020]. 
WONG M.-K. et al., A new and rare species of Luciobrotula from the West Pacific

Guimarães E.C., de Brito P.S., Bragança P.H.N., Santos J.P., Katz A.M., Costa L.F.C. \& Ottoni F.P. 2020. Integrative taxonomy reveals two new cryptic species of Hyphessobrycon Durbin, 1908 (Teleostei: Characidae) from the Maracaçumé and middle Tocantins River basins, Eastern Amazon region. European Journal of Taxonomy 723: 77-107. https://doi.org/10.5852/ejt.2020.723.1145

Hebert P.D., Penton E.H., Burns J.M., Janzen D.H. \& Hallwachs W. 2004. Ten species in one: DNA barcoding reveals cryptic species in the neotropical skipper butterfly Astraptes fulgerator. Proceedings of the National Academy of Sciences 101 (41): 14812-14817. https://doi.org/10.1073/pnas.0406166101

Hung K.-W., Russell B.C. \& Chen W.-J. 2017. Molecular systematics of threadfin breams and relatives (Teleostei, Nemipteridae). Zoologica Scripta 46 (5): 536-551. https://doi.org/10.1111/zsc.12237

Kimura M. 1980. A simple method for estimating evolutionary rates of base substitutions through comparative studies of nucleotide sequences. Journal of Molecular Evolution 16 (2): 111-120. https://doi.org/10.1007/BF01731581

Kumar S., Stecher G., Li M., Knyaz C. \& Tamura K. 2018. MEGA X: molecular evolutionary genetics analysis across computing platforms. Molecular Biology and Evolution 35 (6): 1547-1549.

https://doi.org/10.1093/molbev/msy096

Lee B.-Y., De Forges B.R. \& Ng P.-K. 2019. Deep-sea spider crabs of the family Epialtidae MacLeay, 1838, from Papua New Guinea, with a redefinition of Tunepugettia Ng, Komai \& Sato, 2017, and descriptions of two new genera (Crustacea: Decapoda: Brachyura: Majoidea). Zootaxa 4619 (1): 1-44. https://doi.org/10.11646/zootaxa.4619.1.1

Lee S.-H., Lee M.-Y., Matsunuma M. \& Chen W.-J. 2019. Exploring the phylogeny and species diversity of Chelidoperca (Teleostei: Serranidae) from the western Pacific Ocean by an integrated approach in systematics, with descriptions of three new species and a redescription of C. lecromi Fourmanoir, 1982. Frontiers in Marine Science 6: 465. https://doi.org/10.3389/fmars.2019.00465

Lo P.-C., Liu S.-H., Nor S.A.M. \& Chen W.-J. 2017. Molecular exploration of hidden diversity in the IndoWest Pacific sciaenid clade. PloS One 12 (7): e0176623. https://doi.org/10.1371/journal.pone.0176623

Nielsen J.G. 2009. A revision of the bathyal genus Luciobrotula (Teleostei, Ophidiidae) with two new species. Galathea Report 22: 141-156.

Nielsen J.G. \& Møller P.R. 2008. New and rare deep-sea ophidiiform fishes from the Solomon Sea caught by the Danish Galathea 3 Expedition. Steenstrupia 30 (1): 21-46.

Nielsen J.G., Cohen D.M., Markle D.F. \& Robins C.R. 1999. FAO species catalogue. Volume 18. Ophidiiform fishes of the world (Order Ophidiiformes). An annotated and illustrated catalogue of pearlfishes, cusk-eels, brotulas and other ophidiiform fishes known to date. FAO Fisheries Synopsis 125 (18): $1-178$.

Møller P.R., Knudsen S.W., Schwarzhans W. \& Nielsen J.G. 2016. A new classification of viviparous brotulas (Bythitidae) - with family status for Dinematichthyidae - based on molecular, morphological and fossil data. Molecular Phylogenetics and Evolution 100: 391-408.

https://doi.org/10.1016/j.ympev.2016.04.008

Okamoto M., Chen W.-J. \& Shinohara G. 2018. Epigonus okamotoi (Perciformes: Epigonidae), a junior synonym of E. draco, with new distributional records for E. atherinoides and E. lifouensis in the West Pacific. Zootaxa 4476 (1): 141-150. https://doi.org/10.11646/zootaxa.4476.1.13

Puillandre N., Lambert A., Brouillet S. \& Achaz G. 2012. ABGD, Automatic Barcode Gap Discovery for primary species delimitation. Molecular Ecology 21 (8): 1864-1877.

https://doi.org/10.1111/j.1365-294X.2011.05239.x 
Radcliffe L. 1913. Descriptions of seven new genera and thirty-one new species of fishes of the families Brotulidae and Carapidae from the Philippine Islands and the Dutch East Indies. Proceedings of the United States National Museum 44 (1948): 135-176. https://doi.org/10.5479/si.00963801.44-1948.135

Rach J., Desalle R., Sarkar I.N., Schierwater B. \& Hadrys H. 2008. Character-based DNA barcoding allows discrimination of genera, species and populations in Odonata. Proceedings of the Royal Society B: Biological Sciences 275 (1632): 237-247. https://doi.org/10.1098/rspb.2007.1290

Robertson D.R., Angulo A., Baldwin C.C., Pitassy D.E., Driskell A., Weigt L.A. \& Navarro I.J. 2017. Deep-water bony fishes collected by the B/O Miguel Oliver on the shelf edge of Pacific Central America: an annotated, illustrated and DNA-barcoded checklist. Zootaxa 4348 (1): 1-125.

https://doi.org/10.11646/zootaxa.4348.1.1

Stamatakis A. 2014. RAxML version 8: a tool for phylogenetic analysis and post-analysis of large phylogenies. Bioinformatics 30 (9): 1312-1313. https://doi.org/10.1093/bioinformatics/btu033

Ward R.D., Zemlak T.S., Innes B.H., Last P.R. \& Hebert P.D. 2005. DNA barcoding Australia's fish species. Philosophical Transactions of the Royal Society B: Biological Sciences 360 (1462): 18471857. https://doi.org/10.1098/rstb.2005.1716

Zhang J., Kapli P., Pavlidis P. \& Stamatakis A. 2013. A general species delimitation method with applications to phylogenetic placements. Bioinformatics 29 (22): 2869-2876.

https://doi.org/10.1093/bioinformatics/btt499

Manuscript received: 23 November 2020

Manuscript accepted: 24 March 2021

Published on: 17 May 2021

Topic editor: Rudy Jocqué

Section editor: Felipe P. Ottoni

Desk editor: Kristiaan Hoedemakers

Printed versions of all papers are also deposited in the libraries of the institutes that are members of the EJT consortium: Muséum national d'histoire naturelle, Paris, France; Meise Botanic Garden, Belgium; Royal Museum for Central Africa, Tervuren, Belgium; Royal Belgian Institute of Natural Sciences, Brussels, Belgium; Natural History Museum of Denmark, Copenhagen, Denmark; Naturalis Biodiversity Center, Leiden, the Netherlands; Museo Nacional de Ciencias Naturales-CSIC, Madrid, Spain; Real Jardín Botánico de Madrid CSIC, Spain; Zoological Research Museum Alexander Koenig, Bonn, Germany; National Museum, Prague, Czech Republic. 


\section{Appendix}

\section{Comparative material}

Luciobrotula bartschi Smith \& Radcliffe, 1913

(6 specimens, 97.9-393.7 $\mathrm{mm} \mathrm{SL}$ )

BISMARCK SEA • 393.7 mm SL; Cape Croisilles off Papua New Guinea, stn CP4033; $4^{\circ} 52^{\prime}$ S, $145^{\circ} 53^{\prime} \mathrm{E} ; 780 \mathrm{~m}$ depth; R/V ALIS, beam trawl, PAPUA NIUGINI expedition; 16 Dec. 2012; NTUM 16627 (tissue sample ID: PNG1082).

EAST CHINA SEA • $181.6 \mathrm{~mm} \mathrm{SL}$; stn CD210, 24 $28^{\prime} \mathrm{N}, 122^{\circ} 12^{\prime} \mathrm{E}$; $1185 \mathrm{~m}$ depth; beam trawl; 30 May 2003; ASIZP0063749.

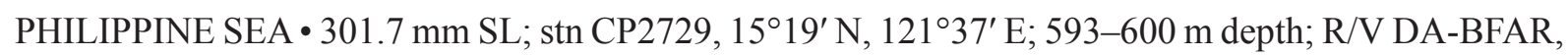
beam trawl, AURORA expedition; 31 May 2007; ASIZP 0068164 (tissue sample ID: ASIZP 0913925).

TAIWAN • 227.4 mm SL; Dashi fishing port; 23 May 2007; ASIZP0070170.

TAIWAN • 97.9 mm SL; South China Sea, NE of Dongsha Island; stn CD321; $20^{\circ} 43^{\prime} \mathrm{N}, 117^{\circ} 32^{\prime} \mathrm{E}$; 954 m depth; beam trawl; 19 Aug. 2005; ASIZP 0066071 (tissue sample ID: ASIZP0911588).

TAIWAN • $202 \mathrm{~mm}$ SL; South China Sea, SE of Little Liuqiu Island; $22^{\circ} 12^{\prime} \mathrm{N}, 120^{\circ} 23^{\prime} \mathrm{E}$; 68-347 m depth; beam trawl; 29 Jul. 2014; ASIZP 0075076 (tissue sample ID: ASIZP 0916618). 